\title{
Plume Migration of Different Carbon Dioxide Phases During Geological Storage in Deep Saline Aquifers
}

\author{
Chien-Hao Shen ${ }^{1}$, Long Nghiem ${ }^{2}$, Ta-Lin Chen ${ }^{3}$, and Bieng-Zih Hsieh ${ }^{1, *}$ \\ ${ }^{1}$ Department of Resources Engineering, National Cheng Kung University, Tainan, Taiwan, R.O.C. \\ ${ }^{2}$ Computer Modelling Group Ltd., Alberta, Canada \\ ${ }^{3}$ Exploration and Development Research Institute, CPC Corporation, Miaoli, Taiwan, R.O.C.
}

Received 30 April 2014, revised 5 August 2014, accepted 5 January 2015

\begin{abstract}
This study estimates the plume migration of mobile supercritical phase (flowing), aqueous phase (dissolved), and ionic phase $\mathrm{CO}_{2}$ (bicarbonate), and evaluates the spatial distribution of immobile supercritical phase (residual) and mineral phase $\mathrm{CO}_{2}$ (carbonates) when $\mathrm{CO}_{2}$ was sequestered. This utilized a simulation, in an anticline structure of a deep saline aquifer in the Tiechenshan (TCS) field, Taiwan. All of the trapping mechanisms and different $\mathrm{CO}_{2}$ phases were studied using the fully coupled geochemical equation-of-state GEM compositional simulator. The mobile supercritical phase $\mathrm{CO}_{2}$ moved upward and then accumulated in the up-dip of the structure because of buoyancy. A large amount of immobile supercritical phase $\mathrm{CO}_{2}$ was formed at the rear of the moving plume where the imbibition process prevailed. Both the aqueous and ionic phase $\mathrm{CO}_{2}$ finally accumulated in the down-dip of the structure because of convection. The plume volume of aqueous phase $\mathrm{CO}_{2}$ was larger than that of the supercritical phase $\mathrm{CO}_{2}$, because the convection process increased vertical sweep efficiency. The up-dip of the structure was not the major location for mineralization, which is different from mobile supercritical phase $\mathrm{CO}_{2}$ accumulation.
\end{abstract}

Key words: Carbon dioxide storage, Deep saline aquifer, Numerical simulation, Plume migration, Trapping mechanism

Citation: Shen, C. H., L. Nghiem, T. L. Chen, and B.Z. Hsieh, 2015: Plume migration of different of carbon dioxide phases during geological storage in deep saline aquifers. Terr. Atmos. Ocean. Sci., 26, 375-386, doi: 10.3319/TAO.2015.01.05.02(TT)

\section{INTRODUCTION}

Storing carbon dioxide $\left(\mathrm{CO}_{2}\right)$ geologically is a technology that benefits from extensive petroleum engineering experience from dealing with hydrocarbon production and storing natural gas (IPCC 2005; IEA 2008). Suitable formations for $\mathrm{CO}_{2}$ storage include depleted oil and gas reservoirs, coal seams, and saline aquifers. Compared with other geological media, deep saline aquifers have the largest storage capacity and can be found in most of the world's sedimentary basins. This is an advantage in terms of $\mathrm{CO}_{2}$ transport from emission sources (IPCC 2005; Bachu 2008).

Several trapping mechanisms act to prevent the buoyant $\mathrm{CO}_{2}$ from coming back to the atmosphere when $\mathrm{CO}_{2}$ is stored in a saline aquifer. These mechanisms include stratigraphic and structural, residual gas, solubility, ionic, and mineral trappings (Pruess et al. 2003; Nghiem et al. 2004, 2009a, b; Kumar et al. 2005; Bachu 2008). Corresponding-

\footnotetext{
* Corresponding author

E-mail:bzhsieh@mail.ncku.edu.tw
}

ly, $\mathrm{CO}_{2}$ mobile and immobile supercritical, aqueous, ionic, and mineral phases exist simultaneously in the aquifer.

When stored in a saline aquifer, $\mathrm{CO}_{2}$ is always less dense and less viscous than the groundwater, making it buoyant and mobile in the aquifer (Bachu 2003). The mobile supercritical $\mathrm{CO}_{2}$ plume will migrate upward, under the impermeable cap rock (Bachu 2008). Over time, other and more secure trapping mechanisms take over. In residual gas trapping, the $\mathrm{CO}_{2}$ is trapped in the rock pore space by capillary pressure (Flett et al. 2004; Bennion and Bachu 2005; Kumar et al. 2005; Juanes et al. 2006; Ide et al. 2007; Bachu 2008; Nghiem et al. 2009a, b, c; Qi et al. 2009). There is no "plume migration" in immobile supercritical phase (residual) $\mathrm{CO}_{2}$ because it is trapped and fixed in the rock pores. The "spatial distribution" of immobile supercritical phase (residual) $\mathrm{CO}_{2}$ is investigated in this study.

Much of the injected $\mathrm{CO}_{2}$ will eventually dissolve into the saline water. This process, which further traps the $\mathrm{CO}_{2}$, is called solubility trapping (Kumar et al. 2005; Bachu 
2008; Nghiem et al. 2009a, b, c). The plume migration of the dissolved $\mathrm{CO}_{2}$ (or aqueous phase $\mathrm{CO}_{2}$ ) is different from that of mobile supercritical $\mathrm{CO}_{2}$, because solubility trapping forms a denser fluid and causes a concentration difference in the saline water, which may then sink to the bottom of the formation (Ennis-King and Paterson 2005).

The dissolved $\mathrm{CO}_{2}$ reacts with formation water and then dissociates into bicarbonate $\left(\mathrm{HCO}_{3}^{-}\right)$and carbonate $\left(\mathrm{CO}_{3}^{2-}\right)$ ions. This chemical reaction is the ionic trapping mechanism (Gunter et al. 2004; Kumar et al. 2005; Bachu 2008; Nghiem et al. 2009a, b). The dissociated bicarbonate ions are referred to as ionic phase $\mathrm{CO}_{2}$ in this study. The plume migration might be similar to that of aqueous $\mathrm{CO}_{2}$ because the ionic phase $\mathrm{CO}_{2}$ is formed from the existing aqueous phase $\mathrm{CO}_{2}$.

Depending on the rock formation, the ionic $\mathrm{CO}_{2}$ may react chemically with the surrounding rocks to form stable minerals. Known as mineral trapping, this process can store $\mathrm{CO}_{2}$ permanently and provides the most secure form of storage for the $\mathrm{CO}_{2}$ (Bachu et al. 1994; Gunter et al. 1997, 2004, 2008; Nghiem et al. 2004, 2009a, b; Rochelle et al. 2004; Xu et al. 2004; Gaus et al. 2005; Thibeau et al. 2007; Bachu 2008). Similar to residual $\mathrm{CO}_{2}$, there is no plume migration in the mineral phase $\mathrm{CO}_{2}$ (i.e., carbonates) because it is precipitated or bound to the rock matrix. The "spatial distribution" of the mineral (solid) phase $\mathrm{CO}_{2}$ is investigated here.

The plume migration and the spatial distribution of different of $\mathrm{CO}_{2}$ phases provide essential information for monitoring, risk assessment, and management issues when a $\mathrm{CO}_{2}$ storage project is developed. The U.S. Environmental Protection Agency (EPA) Underground Injection Control Program requires that the permit applicant define an Area of Review (AOR) in which all penetrations intersecting the injection formation or its confining layer be identified and be determined to have been properly plugged and abandoned when a proposed injection operation has the potential for contaminating underground sources of drinking water through wells, faults or other pathways that penetrate an injection zone (Nicot et al. 2008; EPA 2014). The AOR for a $\mathrm{CO}_{2}$ storage project should be defined and investigated before $\mathrm{CO}_{2}$ is injected into a reservoir. The AOR is traditionally evaluated from the plume migration of mobile supercritical $\mathrm{CO}_{2}$ phase. The integrated AOR evaluation should include all $\mathrm{CO}_{2}$ phase because different $\mathrm{CO}_{2}$ phases have different migration behaviors.

$\mathrm{A} \mathrm{CO}_{2}$ storage project is currently preparing to launch in Taiwan. An onshore saline aquifer of the Yutengping sandstone formation in the Tiechenshan (TCS) field in northwestern Taiwan is a potential site for this project. This study evaluates the AOR from the plume migration of mobile supercritical, aqueous, and ionic $\mathrm{CO}_{2}$, and from the spatial distribution of the immobile supercritical and mineral phase $\mathrm{CO}_{2}$ when $\mathrm{CO}_{2}$ is stored in the anticline structure of a deep saline aquifer in the TCS field.

\section{2. $\mathrm{CO}_{2}$ TRAPPING MECHANISMS AND PLUME MIGRATION}

\subsection{Structural Trapping}

The critical pressure and critical temperature of $\mathrm{CO}_{2}$ are $7376 \mathrm{kPa}$ and $304.2 \mathrm{~K}\left(31^{\circ} \mathrm{C}\right)$, respectively. When $\mathrm{CO}_{2}$ is injected into an aquifer deeper than $800 \mathrm{~m}$, it is in a supercritical state (Bachu 2003). The density of the injected supercritical $\mathrm{CO}_{2}$ is approximately $5160 \mathrm{~kg} \mathrm{~m}^{-3}$ (or $32.9 \mathrm{lb} \mathrm{ft}^{-3}$ ) at reservoir conditions of $16858 \mathrm{kPa}$ (or $2445 \mathrm{psi}$ ) and $72.2^{\circ} \mathrm{C}$ (or $162^{\circ} \mathrm{F}$ ), which is lower than that of saline formation water $\left(10039 \mathrm{~kg} \mathrm{~m}^{-3}\right.$ or $63.9 \mathrm{lb} \mathrm{ft}^{-3}$ at the same reservoir conditions). The flow behavior of supercritical $\mathrm{CO}_{2}$ in an aquifer is similar to that of a fluid (Nghiem et al. 2009a, b). Buoyancy drives the injected $\mathrm{CO}_{2}$ to migrate upward until an impermeable cap rock traps it. Thus, the structural trapping mechanism needs a cap rock to prevent mobile $\mathrm{CO}_{2}$ from leaking out of the storage reservoir (Bachu 2008).

\subsection{Residual Gas Trapping}

Residual gas trapping is the one of the important processes for trapping $\mathrm{CO}_{2}$. The mechanism converts $\mathrm{CO}_{2}$ into an immobile phase in the pores via the capillary effect and imbibition. The imbibition usually occurs at the rear of the plume of supercritical $\mathrm{CO}_{2}$ after the injection stops. The classic Land's model (Land 1968) (Fig. 1) was used in this study to calculate the residual gas $\left(\mathrm{CO}_{2}\right)$ saturation [Eqs. (1) and (2)], as follows (Nghiem et al. 2009a, b):

$S_{g t}^{*}\left(S_{g i}^{*}\right)=\frac{S_{g i}^{*}}{1+C S_{g i}^{*}}$

$C=\frac{1}{S_{g t, \max }}-\frac{1}{S_{g, \max }}$

where $S_{g t}^{*}=$ residual gas saturation corresponding to $S_{g i}^{*}, S_{g i}^{*}$ $=$ the gas saturation value $\left(S_{g}\right)$ when the shift to imbibition

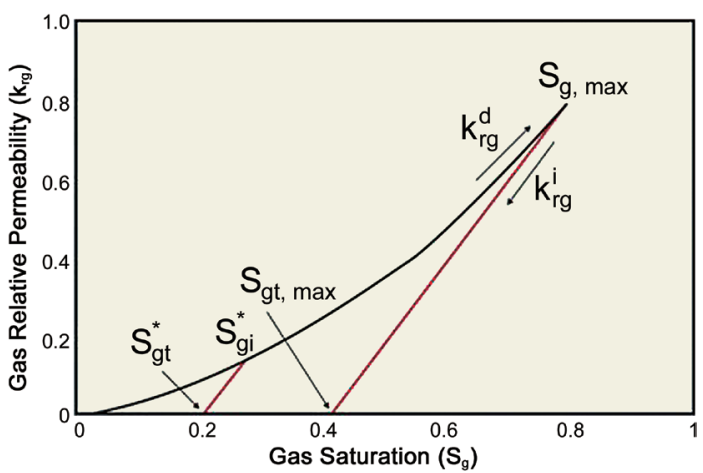

Fig. 1. The Land's residual gas trapping model (Nghiem et al. 2009a). The maximum residual gas saturation is 0.4 . 
occurs. $C=$ Land's coefficient, $S_{g, \max }=$ the maximum gas saturation, $S_{g t, \max }=$ the maximum residual gas saturation.

When the gas saturation $S_{g i}^{*}$ reverses and decreases at drainage curve, the gas relative permeability follows the imbibition curve $k_{r g}^{i}$ (red curve).

\subsection{Solubility Trapping}

Solubility trapping causes both mobile and immobile supercritical $\mathrm{CO}_{2}$ to change into an aqueous phase via the dissolution process. Denser $\mathrm{CO}_{2}$-saturated water will be formed and it will tend to sink to the bottom of the formation. The convection effect will force the fresh water to replace the $\mathrm{CO}_{2}$-saturated water. Consequently, more supercritical $\mathrm{CO}_{2}$ dissolves into the water.

$\mathrm{CO}_{2}$ solubility in brine can be modeled as a phase-equilibrium process. To calculate the quantity of aqueous $\mathrm{CO}_{2}$, the equality of fugacities in the gas and aqueous phase used is as follows (Nghiem et al. 2009a, b):

$f_{\mathrm{CO}_{2}, g}=f_{\mathrm{CO}_{2}, a q}$

In this study, the fugacity of $\mathrm{CO}_{2}$ in the gas phase $\left(f_{\mathrm{CO}_{2}, g}\right)$ was calculated using the Peng-Robinson equation-of-state (EOS) (Peng and Robinson 1976), and the fugacity of $\mathrm{CO}_{2}$ in the aqueous phase $\left(f_{\mathrm{CO}_{2}, a q}\right)$ was modeled with Henry's law (Li and Nghiem 1986), as follows:

$f_{\mathrm{CO}_{2}, a q}=y_{\mathrm{CO}_{2}, a q} \cdot H_{\mathrm{CO}_{2}}$

where $y_{\mathrm{CO}_{2}, a q}=$ the mole fraction of $\mathrm{CO}_{2}$ in the aqueous phase and $\mathrm{H}_{\mathrm{CO}_{2}}=$ Henry's constant of $\mathrm{CO}_{2}$, which is a function of pressure, temperature and salinity.

Gas solubility increases with increasing pressure and decreases with increasing temperature or salinity (Nghiem et al. 2009a, b). The correlations derived by Harvey (1996), Garcia (2001), and Bakker (2003) are used to obtain an accurate prediction of $\mathrm{CO}_{2}$ solubility in water (Nghiem et al. 2009a, b; CMG 2011a).

\subsection{Ionic Trapping}

The $\mathrm{H}^{+}$and $\mathrm{HCO}_{3}^{-}$or $\mathrm{CO}_{3}^{2-}$ ions are dissociated when the injected $\mathrm{CO}_{2}$ dissolves in water. The main chemical reactions related to $\mathrm{CO}_{2}$ sequestration are as follows:

$\mathrm{CO}_{2(a q)}+\mathrm{H}_{2} \mathrm{O} \leftrightarrow \mathrm{H}^{+}+\mathrm{HCO}_{3}^{-}$

$\mathrm{HCO}_{3}^{-} \leftrightarrow \mathrm{H}^{+}+\mathrm{CO}_{3}^{2-}$

where $\mathrm{CO}_{2(a q)}=$ the $\mathrm{CO}_{2}$ that is dissolved in the aqueous phase (from solubility trapping).
Chemical equilibrium reactions were used in this study to model this fast and reversible intra-aqueous chemical reaction (ionic trapping mechanism) (Nghiem et al. 2009a, b). The chemical equilibrium reactions were governed by chemical equilibrium constants (Bethke 1996; Nghiem et al. 2009a, b), as follows:

$Q_{\alpha}-K_{e q, \alpha}=0, \alpha=1, \ldots, R_{a q}$

where $R_{a q}=$ the number of intra-aqueous chemical equilibrium reactions, $K_{e q, \alpha}=$ the chemical equilibrium constant for the aqueous reaction $\alpha$, and $Q_{\alpha}=$ the activity product for the aqueous reaction $\alpha$.

The values of $K_{e q, \alpha}$ for several aqueous reactions were studied by Kharaka et al. (1988) and Delaney and Lundeen (1990). The activity product $\left(Q_{\alpha}\right)$ is calculated by (Nghiem et al. 2009a, b):

$Q_{\alpha}=\prod_{k=1}^{n_{a q}} a_{k}^{v_{k, \alpha}}$

where $n_{a q}=$ the number of aqueous components, $a_{k}=$ the activity of component $k$, and $v_{k, \alpha}=$ the stoichiometry coefficients of the chemical equilibrium reactions.

The activities $a_{k}$ are the product of the molality $\left(m_{k}\right.$, moles per $\mathrm{kg}$ of $\left.\mathrm{H}_{2} \mathrm{O}\right)$ and the activity coefficient $\left(\gamma_{k}\right)$ of component $k$. An efficient model for calculating the ionic activity coefficients is the $B$-dot model for the non-ideal solution (Bethke 1996) or the Pitzer (1987) model for a highsalinity solution (Nghiem et al. 2009a, b).

\subsection{Mineral Trapping}

The ions that are dissociated through the chemical equilibrium reaction will react with the minerals in place, and with other ions in the solution, and will lead to the precipitation of carbonate minerals or the dissolution of formation minerals. The typical geochemical reaction for the precipitation or dissolution of calcite $\left(\mathrm{CaCO}_{3}\right)$ is:

Calcite $+\mathrm{H}^{+} \leftrightarrow \mathrm{Ca}^{2+}+\mathrm{HCO}_{3}^{-}$

Geochemical reactions occur between minerals and aqueous components, and are reversible. The dissolution or precipitation of minerals follows the reaction rate $\left(r_{\beta}\right)$, given by (Bethke 1996; Nghiem et al. 2009a, b):

$r_{\beta}=\hat{\mathrm{A}}_{\beta} k_{\beta}\left(1-\frac{Q_{\beta}}{K_{e q, \beta}}\right), \beta=1, \ldots, R_{m n}$

where $r_{\beta}=$ the reaction rate for a given mineral $\beta, R_{m n}=$ the number of mineral reactions, $\hat{\mathrm{A}}_{\beta}=$ the reactive surface 
area, $k_{\beta}=$ the rate constant of the mineral reaction, $K_{e q, \beta}=$ the chemical equilibrium constant of the mineral reaction, and $Q_{\beta}=$ the activity product of the mineral reaction.

The ratio of the activity product to the chemical equilibrium constant $\left(Q_{\beta} / K_{e q, \beta}\right)$ is the saturation index (SI) of the reaction and is used to evaluate the dissolution or precipitation path (Nghiem et al. 2009a, b). The changes in the moles of minerals through dissolution or precipitation can be estimated after the geochemical reaction occurs.

\section{GEOLOGICAL SETTING AND ENGINEERING DATA}

This case study area is located in the Taihsi basin, in northwest Taiwan. The Taihsi basin is situated near the Taiwan mountain ranges with the eastern boundary of the deformation front (Fig. 2). To the North and South, the Taihsi basin is bounded by the Kuanyin uplift and Penghu platform, respectively (Fig. 2). The west of the Taihsi basin connects with the Taiwan Strait shelf. The thickness of the Taihsi basin is about $8 \mathrm{~km}$. The formation dip angle is about $4^{\circ}$ from west to east, which is caused by the orogenic load of the Taiwan mountain ranges (Lin 2001; Lin et al. 2003).

The Cenozoic sediments of the Taihsi basin, which have the highest capacity for $\mathrm{CO}_{2}$ storage in Taiwan (Lin 2007), can be divided by three evolution episodes: the PaleoceneEocene syn-rift, the Oligocene-Miocene post-breakup, and the Latest Miocene-Recent foreland basin (Lin et al. 2003). The sedimentary formations in the Oligocene-Miocene postbreakup period, from bottom to top, are the Wuchihshan, Mushan, Piling, Shihti, and Nankang formations, which are the major gas reservoirs and hydrocarbon source rocks in Taiwan (Fig. 3). The sedimentary formations in the latest Miocene-Recent foreland basin are the Kueichulin, Chinshui, Cholan, and Toukoshan formations, which are saline aquifers (Fig. 3).

The Kueichulin formation was selected for the $\mathrm{CO}_{2}$ storage project in the Taihsi basin, because its depth interval is suitable for the storage of $\mathrm{CO}_{2}$ in its supercritical state (Bachu 2003; Lin 2007). The Kueichulin formation is divided into three parts: Yutengping sandstone, Shihliufen shale, and Kuantaoshan sandstone (Fig. 3). The Yutengping sandstone is the top layer and is overlain by the impermeable Chinshui shale (Fig. 3). The thickness of the Chinshui shale is approximately $300 \mathrm{~m}$ and its permeability is extremely low, less than $10^{-4} \mathrm{md}$. The Chinshui shale is the caprock and will prevent $\mathrm{CO}_{2}$ leakage after $\mathrm{CO}_{2}$ has been injected into the Yutengping sandstone for storage. The Yutenping sandstone lies on top of the Shihliufen shale, which is treated as the impermeable lower boundary of the $\mathrm{CO}_{2}$ storage formation.

The selected potential storage site is an anticline trap with a closure depth of $1600 \mathrm{~m}$ (Fig. 4). The formation parameters of Yutengping sandstone (Table 1) were collected from the available drilling reports, core analyses, and well

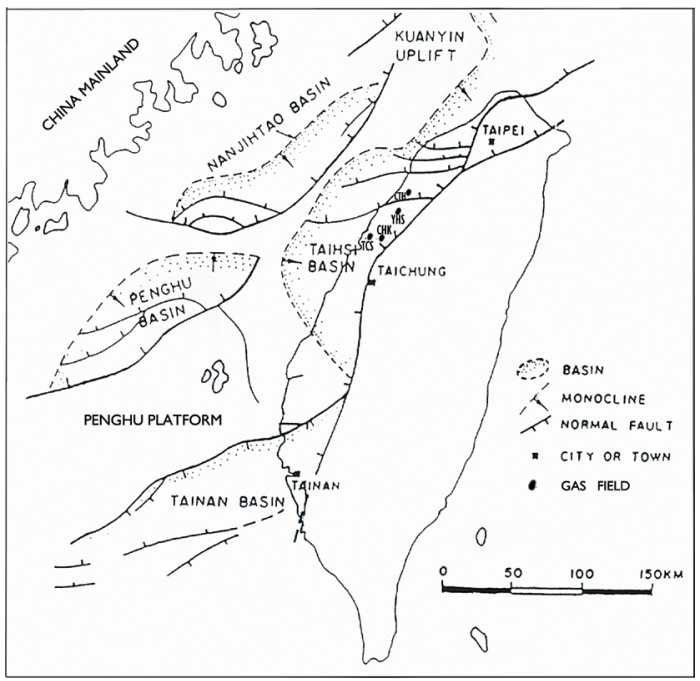

Fig. 2. Location of the Taihsi basin. The black dots show the location of major gas fields (based on Hsieh et al. 2013).

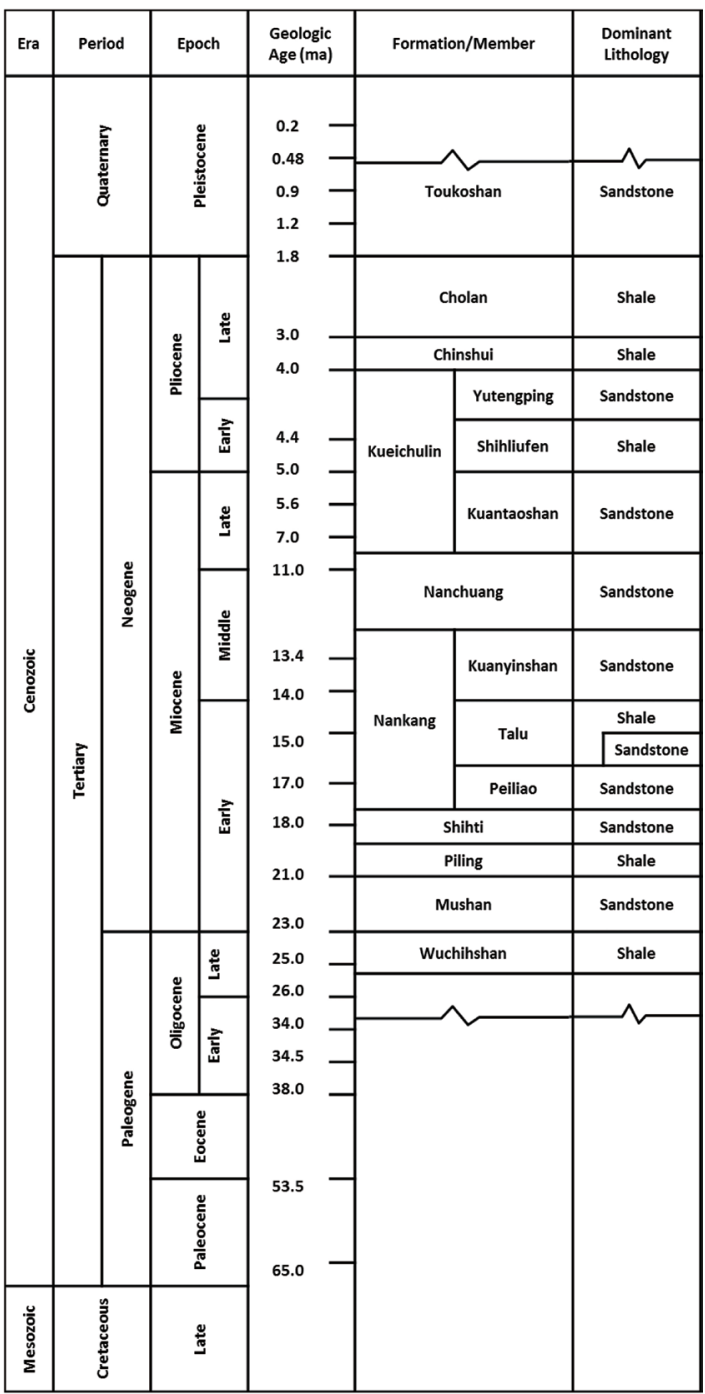

Fig. 3. Stratigraphic nomenclature and lithology of the sedimentary succession in the Taihsi basin (after Shaw 1996; Wu et al. 2005). 


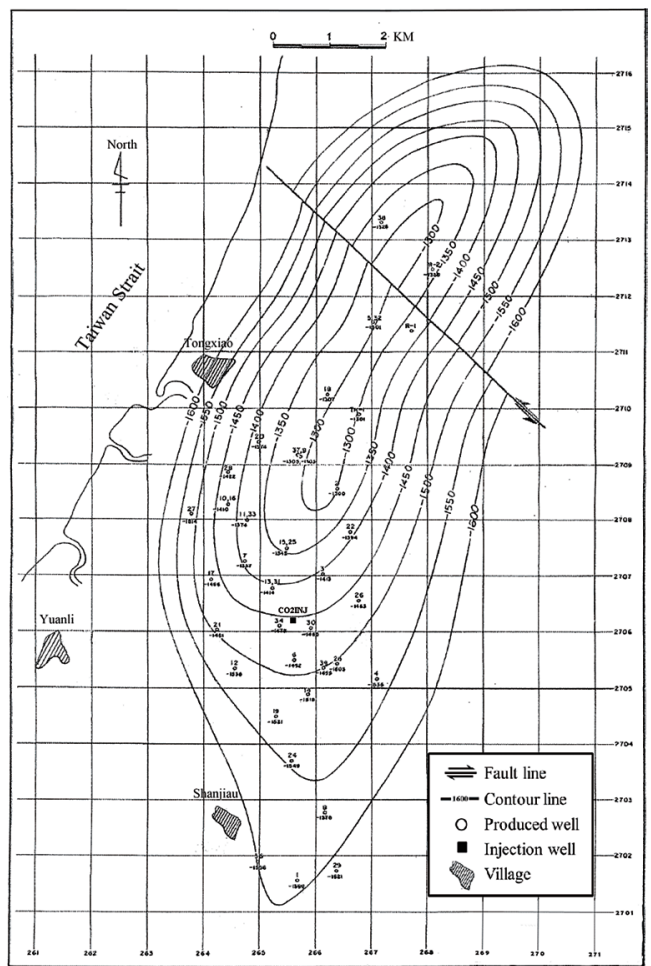

Fig. 4. Anticline structure map of the Yutengping sandstone formation in the TCS field (based on CPC 2010).

Table 1. Basic parameters of the Yutengping sandstone formation.

\begin{tabular}{cc}
\hline Parameter (unit) & Value \\
\hline Formation Top (m) & $1300-1600$ \\
Reservoir Size $\left(\mathrm{m}^{2}\right)$ & $6.65 \mathrm{E} 7$ \\
Grid size $\left(\mathrm{m}^{3}\right)$ & $228.6 \times 228.6 \times 41$ \\
Porosity (frac.) & 0.2 \\
Thickness (m) & 205 \\
Permeability (md) & 300 \\
Horizontal to Vertical Permeability Ratio & 1 \\
Initial Pressure (MPa) & 15.7 \\
Reference Depth for Initial Pressure (m) & 1547 \\
Temperature $\left({ }^{\circ} \mathrm{C}\right)$ & 72 \\
Maximum Gas Saturation (frac.) & 0.8 \\
Maximum Residual Gas Saturation (frac.) & 0.4 \\
Salinity of the Formation Water Fluid (ppm) & 16000 \\
\hline
\end{tabular}

Note: $a: m d \times 9.869 E-16=m^{2}$.

logging interpretations from Taiwan's CPC Corporation.

Formation water samples from the Yutengping sandstone were laboratory analyzed and their composition Table 2 was corrected using a geochemical aqueous equilibrium model, Solmineq.88 (Kharaka et al. 1988; GAMS 2011b). XRF (X-ray fluorescence) and XRD (X-ray diffraction) were used to analyze the volume percentage of rock minerals (Table 3) was analyzed form a formation rock sample.

A geochemical reaction path model, GAMSPath (GAMS 2011a), was used to analyze the intra-aqueous chemical reactions and geochemical reaction paths of rockbrine- $\mathrm{CO}_{2}$ in a preliminary theoretical study, in which the injection of $\mathrm{CO}_{2}$ into brine was simulated. The aqueous phase $\mathrm{CO}_{2}\left[\mathrm{CO}_{2(a q)}\right]$ was formed and the bicarbonate $\left(\mathrm{HCO}_{3}^{-}\right)$ions were then dissociated in the solution. Consequently, the $\mathrm{pH}$ value of the solution was lowered. This caused variations in the kaolinite and muscovite early in the simulated period. A small amount of muscovite was dissolved and kaolinite was precipitated. However, anorthite was dissolved continuously in the low $\mathrm{pH}$ solution, which dissociated the calcium $\left(\mathrm{Ca}^{2+}\right)$ and aluminum $\left(\mathrm{Al}^{3+}\right)$ in the solution. The reaction between the bicarbonate $\left(\mathrm{HCO}_{3}^{-}\right)$and calcium $\left(\mathrm{Ca}^{2+}\right)$ finally led to the precipitation of calcite $\left(\mathrm{CaCO}_{3}\right)$. Kaolinite, another secondary mineral, was precipitated because of the dissociated aluminum $\left(\mathrm{Al}^{3+}\right)$. Based on the geochemical reaction analysis result we concluded that there were ten rock-brine- $\mathrm{CO}_{2}$ interactions: five intra-aqueous chemical reactions in the aqueous phase and five geochemical mineral reactions in the mineral phase (Table 4).

\section{RESERVOIR SIMULATION MODEL CONSTRUCTION}

The numerical simulation method was used in this study to estimate the plume migration of the supercritical, dissolved, and ionic $\mathrm{CO}_{2}$ to evaluate the spatial distribution of the residually and mineralogically trapped $\mathrm{CO}_{2}$ in a saline aquifer. The fully coupled geochemical equation-ofstate model (GEM) simulator was used with the GEM-GHG module, a commercial reservoir simulator developed by CMG (Computer Modelling Group Ltd.), which is capable of modeling all trapping mechanisms (Nghiem et al. 2009a, b; CMG 2011a).

The numerical geological model was constructed by dividing the structure into 6365 grids and assuming an open boundary on the edge grid. Each grid is uniform in size (about $228.6 \times 228.6 \times 41 \mathrm{~m}$ ), and we divided the reservoir into 5 layers to illustrate the vertical migration path. The rock and fluid properties (formation parameters, fluid PVT data, and relative permeability curves) and formation initial conditions (initial formation pressure, reservoir temperature, formation water analysis data, and rock mineral compositions) were sequentially assigned to each grid block. The specific operation (by designing injection rates or injection pressures) and completion (perforation intervals) conditions were then used to create a model of a well for injecting $\mathrm{CO}_{2}$ into the aquifer.

To simulate the residual gas trapping, the maximum gas saturation $\left(S_{g, \max }\right)$ and maximum residual gas saturation $\left(S_{g t, \text { max }}\right)$ (Table 1) were used to calculate the Land's 
coefficient $(C)$ [Eq. (2)] and to estimate the residual gas saturation $\left(S_{g t}^{*}\right)$ from the Land's model [Eq. (1)]. The hysteresis effect on the gas relative permeability was modeled. The solubility trapping mechanism was modeled from the phase-equilibrium process (Nghiem et al. 2009a, b). The Peng-Robinson EOS and Henry's law parameters, which were used to calculate the fugacities of $\mathrm{CO}_{2}$ in the gas and aqueous phases, were derived from a phase property program: WinProp (CMG 2011b).

This case study was simulated to inject one million tons of $\mathrm{CO}_{2}$ per year, to create a commercial site for $\mathrm{CO}_{2}$ storage, with an injection period of 20 years, to create an oil development project life cycle, under the constraint of injection pressure lower than the fracture pressure, for the case of a vertical well at the down-dip of an anticline structure. The total simulation period for studying the plume migration and spatial distribution of the different phases of $\mathrm{CO}_{2}$ at various times was 1000 years.

\section{RESULTS}

When $\mathrm{CO}_{2}$ is injected into an aquifer, the plume of supercritical $\mathrm{CO}_{2}$ tends to move upward because of the $\mathrm{CO}_{2}$ buoyant force (Figs. 5a, b). Consequently, the plume is stopped by the cap rock because the cap rock is impermeable. Supercritical $\mathrm{CO}_{2}$ then flows under the cap rock, following the structure inclination and migrating to the structure up-dip (Fig. 5c).

In the post-injection period, the supercritical $\mathrm{CO}_{2}$ continuously migrates to the structure up-dip and accumulates in the trap (Fig. 5d). Some supercritical $\mathrm{CO}_{2}$ is trapped in the pores and becomes immobile at the rear of the moving plume. Solubility trapping also reduces the size of the supercritical $\mathrm{CO}_{2}$ plume phase, especially in the area of the immobile supercritical $\mathrm{CO}_{2}$ (Figs. 5e, f).

During $\mathrm{CO}_{2}$ injection period supercritical $\mathrm{CO}_{2}$ is continuously injected into the aquifer to drain the formation water away from the wellbore. In this drainage process, there is no residual $\mathrm{CO}_{2}$ (or immobile supercritical $\mathrm{CO}_{2}$ ) formed (Figs. 6a, b). At the end of the injection period, a few pockets of residual $\mathrm{CO}_{2}$ are formed around the rear side of the plume (Fig. 6c).

In the post-injection period, supercritical $\mathrm{CO}_{2}$ is no longer injected and imbibition occurs. Residually trapped $\mathrm{CO}_{2}$ is formed behind the moving supercritical $\mathrm{CO}_{2}$ plume (Fig. 6d). The amount of residual $\mathrm{CO}_{2}$ reaches a maximum at the simulation time of 100 years $(80$ years after the end of $\mathrm{CO}_{2}$ injection). The solubility trapping mechanism then works to reduce the immobile supercritical $\mathrm{CO}_{2}$ volume because the trapped $\mathrm{CO}_{2}$ dissolves into the water (Fig. 6e). At the simulation time of 1000 years, the greater part of the immobile supercritical $\mathrm{CO}_{2}$ is dissolved into the formation water (Fig. 6f).

The simulation results show that the residual gas trap- ping mechanism is a fast and safe mechanism in the postinjection period because it fixes a great deal of mobile supercritical $\mathrm{CO}_{2}$ and provides a good environment for the solubility trapping mechanism to operate.

When mobile or immobile supercritical $\mathrm{CO}_{2}$ contacts the formation water, $\mathrm{CO}_{2}$ dissolves into the water and aqueous $\mathrm{CO}_{2}$ forms. The simulation results show that the aqueous plume migration $\mathrm{CO}_{2}$ (Figs. $7 \mathrm{a}-\mathrm{c}$ ) is similar to that of supercritical $\mathrm{CO}_{2}$ (Figs. 5a - c) in a 20-year injection period. However, the aqueous $\mathrm{CO}_{2}$ plume size is larger than that of supercritical $\mathrm{CO}_{2}$ because of the convection effect. Because $\mathrm{CO}_{2}$-saturated water is heavier than the original formation water, it tends to sink to the bottom of the formation (Figs. $7 \mathrm{a}-\mathrm{c}$ ), while the supercritical $\mathrm{CO}_{2}$ tends to move

Table 2. Aqueous composition reported for the Yutengping sandstone.

\begin{tabular}{cc}
\hline Species & Molality $(\mathbf{m o l ~ k g - 1})$ \\
\hline $\mathrm{H}^{+}$ & $2.64 \mathrm{E}-09$ \\
$\mathrm{Al}^{3+}$ & $2.32 \mathrm{E}-11$ \\
$\mathrm{Ca}^{2+}$ & $5.46 \mathrm{E}-05$ \\
$\mathrm{SiO}_{2(a q)}$ & $2.38 \mathrm{E}-04$ \\
$\mathrm{~K}^{+}$ & $2.85 \mathrm{E}-04$ \\
$\mathrm{HCO}_{3}^{-}$ & $1.27 \mathrm{E}-02$ \\
$\mathrm{CO}_{3}^{2-}$ & $9.83 \mathrm{E}-04$ \\
\hline
\end{tabular}

Table 3. Volume percentage of minerals of formation rock.

\begin{tabular}{cc}
\hline Mineral & Volume percentage \\
\hline Quartz $\left(\mathrm{SiO}_{2}\right)$ & $95.6 \%$ \\
Anorthite $\left(\mathrm{CaAl}_{2} \mathrm{Si}_{2} \mathrm{O}_{8}\right)$ & $1.1 \%$ \\
Kaolinite $\left(\mathrm{Al}_{2} \mathrm{Si}_{2} \mathrm{O}_{5}(\mathrm{OH})_{4}\right)$ & $2.3 \%$ \\
Muscovite $\left[\mathrm{KAl}_{3} \mathrm{Si}_{3} \mathrm{O}_{10}(\mathrm{OH})_{2}\right]$ & $1.0 \%$ \\
\hline
\end{tabular}

Table 4. Major intra-aqueous chemical reactions and geochemical mineral reactions considered in this study.

\begin{tabular}{c} 
Major reactions \\
\hline Intra-aqueous chemical reactions \\
$\mathrm{CO}_{2(a q)}+\mathrm{H}_{2} \mathrm{O} \leftrightarrow \mathrm{H}^{+}+\mathrm{HCO}_{3}^{-}$ \\
$\mathrm{CO}_{3}^{2-}+\mathrm{H}^{+} \leftrightarrow \mathrm{HCO}_{3}^{-}$ \\
$\mathrm{OH}^{-}+\mathrm{H}^{+} \leftrightarrow \mathrm{H}_{2} \mathrm{O}$ \\
$\mathrm{Al}(\mathrm{OH})^{2+}+\mathrm{H}^{+} \leftrightarrow \mathrm{Al}^{3+}+\mathrm{H}_{2} \mathrm{O}$ \\
$\mathrm{KOH}+\mathrm{H}^{+} \leftrightarrow \mathrm{K}^{+}+\mathrm{H}_{2} \mathrm{O}$ \\
\hline Geochemical mineral reactions \\
$\mathrm{Calcite}+\mathrm{H}^{+} \leftrightarrow \mathrm{Ca}^{2+}+\mathrm{HCO}_{3}^{-}$ \\
Anorthite $+8 \mathrm{H}^{+} \leftrightarrow 4 \mathrm{H}_{2} \mathrm{O}+\mathrm{Ca}^{2+}+2 \mathrm{Al}^{3+}+2 \mathrm{SiO}_{2(a q)}$ \\
Kaolinite $+6 \mathrm{H}^{+} \leftrightarrow 5 \mathrm{H}_{2} \mathrm{O}+2 \mathrm{Al}^{3+}+2 \mathrm{SiO}_{2(a q)}$ \\
Muscovite $+6 \mathrm{H}^{+} \leftrightarrow 6 \mathrm{H}_{2} \mathrm{O}+\mathrm{K}^{+}+3 \mathrm{Al}^{3+}+3 \mathrm{SiO}_{2(a q)}$ \\
Quartz $\leftrightarrow \mathrm{SiO}_{2(a q)}$ \\
\hline
\end{tabular}




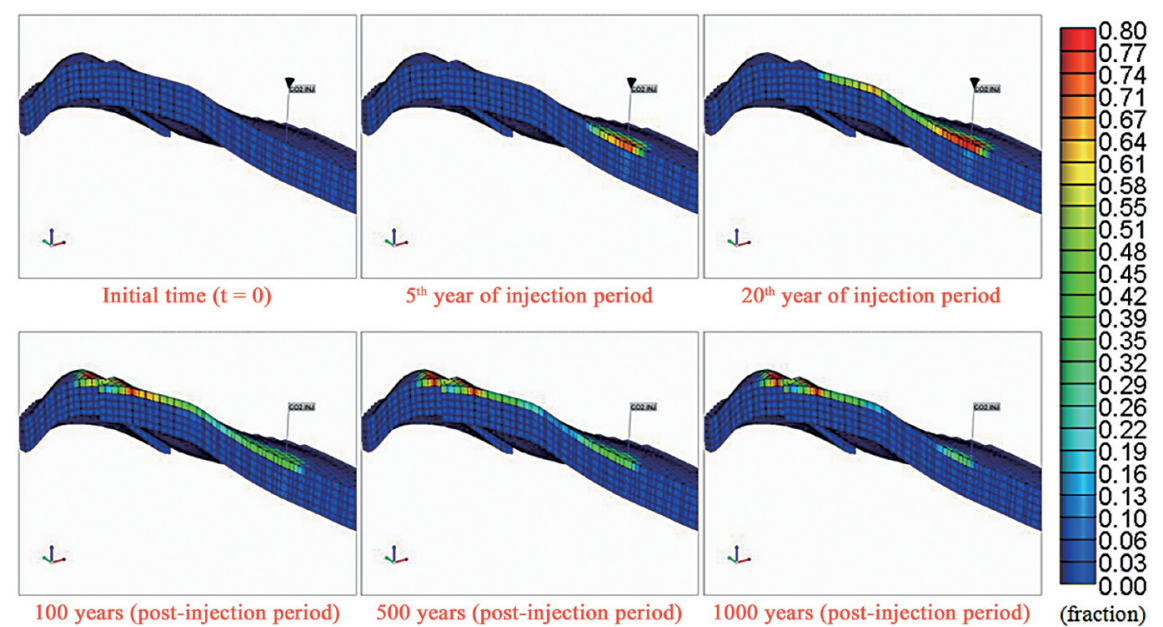

Fig. 5. Plume migration of supercritical phase $\mathrm{CO}_{2}$ at various times: (a) initial time (the beginning of the injection period), (b) 5 years, (c) 20 years (the end of the injection period), (d) 100 years, (e) 500 years, (f) 1000 years (the end of simulation time).

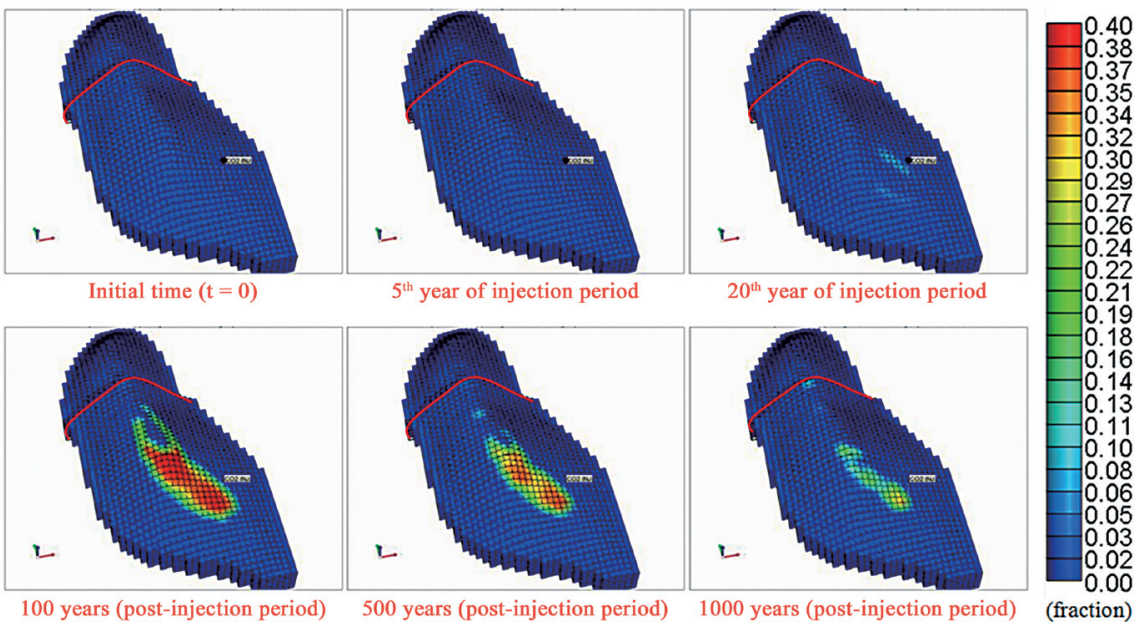

Fig. 6. Immobile supercritical phase (residual) $\mathrm{CO}_{2}$ spatial distribution at various times: (a) initial time (the beginning of the injection period), (b) 5 years, (c) 20 years (the end of the injection period), (d) 100 years, (e) 500 years, (f) 1000 years (the end of simulation time).

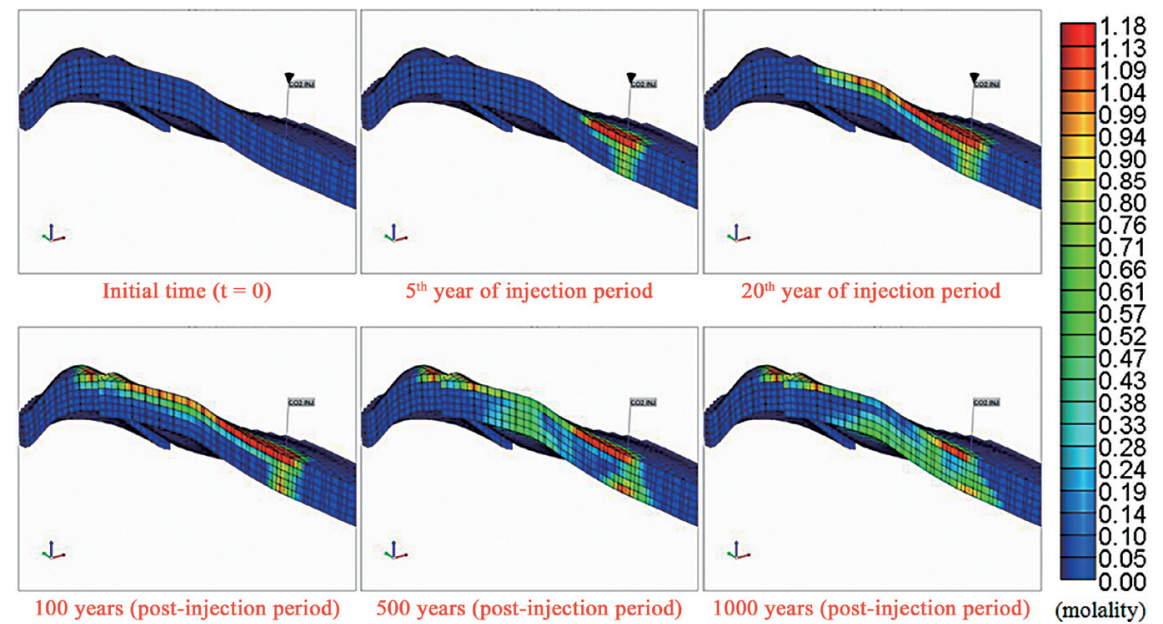

Fig. 7. Aqueous phase $\mathrm{CO}_{2}$ plume migration at various times: (a) initial time (the beginning of the injection period), (b) 5 years, (c) 20 years (the end of the injection period), (d) 100 years, (e) 500 years, (f) 1000 years (the end of simulation time). 
upward to the top of the structure (Figs. $5 \mathrm{a}-\mathrm{c}$ ). During the $\mathrm{CO}_{2}$ injection period, the difference in migration behavior between the aqueous $\mathrm{CO}_{2}$ (Fig. 7c) and supercritical $\mathrm{CO}_{2}$ (Fig. 5c) plumes is easily seen, especially in the vicinity of the wellbore.

In the post-injection period, convection transfers a large amount of aqueous $\mathrm{CO}_{2}$ to the bottom of the formation. The aqueous $\mathrm{CO}_{2}$ finally accumulates in the down-dip of the structure (Figs. 7d - f), where it is safe and distant from the cap rock. The plume migration of aqueous $\mathrm{CO}_{2}$ shows that the risk for $\mathrm{CO}_{2}$ leakage can be lowered when the solubility trapping mechanism operates continuously.

The simulation results show that the plume migration of ionic $\mathrm{CO}_{2}\left(\mathrm{HCO}_{3}^{-}\right)$(Figs. 8a - $\mathrm{f}$ ) is very similar to that of aqueous $\mathrm{CO}_{2}$ (Figs. 7a-f). This is because the ionic $\mathrm{CO}_{2}$ is formed from the aqueous $\mathrm{CO}_{2}$ and formation water $\left(\mathrm{H}_{2} \mathrm{O}\right)$ reaction. In other words, the aqueous $\mathrm{CO}_{2}$ plume is the cradle for creating ionic phase $\mathrm{CO}_{2}$. During $\mathrm{CO}_{2}$ injection the ionic $\mathrm{CO}_{2}\left(\mathrm{HCO}_{3}^{-}\right)$(Figs. 8a - c) plume migration is similar to that of supercritical $\mathrm{CO}_{2}$ (Figs. $5 \mathrm{a}-\mathrm{c}$ ). The convection effect, which dominates the plume migration of aqueous $\mathrm{CO}_{2}$, also affects the plume migration of ionic $\mathrm{CO}_{2}$. In the postinjection period convection causes a large amount of aqueous $\mathrm{CO}_{2}$ to sink to the bottom of the formation (Figs. 7d - f). Consequently, the ionic $\mathrm{CO}_{2}\left(\mathrm{HCO}_{3}^{-}\right)$plume has the same flow behavior (Figs. 8d - f). Similar to aqueous $\mathrm{CO}_{2}$, ionic phase $\mathrm{CO}_{2}\left(\mathrm{HCO}_{3}^{-}\right)$tends to sink and accumulate in the down-dip of the structure. Ionic $\mathrm{CO}_{2}$ is also distant from the cap rock. Based on the simulation results the ionic trapping mechanism changes the phase of $\mathrm{CO}_{2}$ into a safer ionic phase and generates flow behavior that is low-leakage-risk and allows safe storage.

The precipitation of carbonates is because of the reaction between the ionic $\mathrm{CO}_{2}\left(\mathrm{HCO}_{3}^{-}\right)$and rock minerals. In this case study, anorthite dissolved in the low $\mathrm{pH}$ environment yielded calcium $\left(\mathrm{Ca}^{2+}\right)$. Calcite $\left(\mathrm{CaCO}_{3}\right)$ was precipitated from the reaction between the bicarbonate $\left(\mathrm{HCO}_{3}^{-}\right)$ and the calcium $\left(\mathrm{Ca}^{2+}\right)$. Calcite $\left(\mathrm{CaCO}_{3}\right)$ is the major mineral phase $\mathrm{CO}_{2}$ in this case study. Our simulation results show that the $\mathrm{pH}$ value of the formation water was lowered after $\mathrm{CO}_{2}$ was injected into the formation, and that the variations in the kaolinite and muscovite were caused first. A small amount of muscovite was dissolved and kaolinite was precipitated. The simulation results were identical to the observations from the preliminary GAMSPath theoretical study (GAMS 2011a).

The simulation results show that there is no calcite precipitation during the 20-year injection period (Figs. 9a - c). Moreover, the precipitation of kaolinite and the dissolution of muscovite did not substantially affect the formation porosity. Based on the simulation results, there were almost no changes in formation porosity during the injection period.

In the post-injection period calcite precipitation was the predominant reaction during mineralization. After 100 years a small amount of calcite precipitated into the formation pores where the ionic $\mathrm{CO}_{2}$ plume had formed (Fig. 9d). The ionic $\mathrm{CO}_{2}$ plume was the source of the calcite precipitation (Figs. 8e, 9e). The up-dip of the structure was not the major location of mineralization (Fig. 9f) because the source (bicarbonate) of the mineralization tended to sink to the bottom of the structure. Moreover, the dynamic changes in the formation porosity were related to the mineral $\mathrm{CO}_{2}$ $\left(\mathrm{CaCO}_{3}\right)$ spatial distribution. At the end of the simulation (1000 years), the formation porosity had decreased by $0.2 \%$ near the wellbore. The wellbore vicinity is where most damage to the formation porosity occurred.

\section{DISCUSSION}

The flow path and velocity of supercritical $\mathrm{CO}_{2}$ is essential information for evaluating the AOR and for monitoring and safety in a $\mathrm{CO}_{2}$ storage project. In this study, the flow path of the supercritical $\mathrm{CO}_{2}$ was traced and the velocity of the supercritical $\mathrm{CO}_{2}$ was estimated from the plume front moving distance of supercritical $\mathrm{CO}_{2}$.

The plume of supercritical $\mathrm{CO}_{2}$ first moved northwest, turned north-northwest, and accumulated in the up-dip of the structure (Fig. 10). By investigating the plume area at the end of the injection period (Fig. 10), we saw that the average the supercritical $\mathrm{CO}_{2}$ plume velocity was about $320 \mathrm{~m}_{\text {year }}{ }^{-1}$ $\left(1050 \mathrm{ft} \mathrm{year}^{-1}\right)$ or about $0.88 \mathrm{~m} \mathrm{day}^{-1}\left(2.9 \mathrm{ft} \mathrm{day}^{-1}\right)$ during the 20-year injection period.

In the post-injection period the supercritical $\mathrm{CO}_{2}$ velocity slowed because $\mathrm{CO}_{2}$ was no longer being injected. The trap of the structure restricted supercritical $\mathrm{CO}_{2}$ plume extension. Based on our results, the area size of the supercritical $\mathrm{CO}_{2}$ plume was the largest at the simulation time of 60 years (40 years after the end of injection) (Figs. 11a, b). The area size of the supercritical $\mathrm{CO}_{2}$ was about $13.9 \mathrm{~km}^{2}$ (Fig. 11a) and the volume of the supercritical $\mathrm{CO}_{2}$ was about $0.45 \mathrm{~km}^{3}$ (Fig. 11b). The plume volume was relatively small. The vertical sweep efficiency affected the plume volume because the supercritical $\mathrm{CO}_{2}$ always flowed on the top of the formation because of its buoyancy (Fig. 11b).

The size of the area and the volume of the aqueous $\mathrm{CO}_{2}$ were also investigated and compared. The area size of the aqueous $\mathrm{CO}_{2}$ was about $16.7 \mathrm{~km}^{2}$ (Fig. 11c) and the aqueous $\mathrm{CO}_{2}$ plume volume was about $2.55 \mathrm{~km}^{3}$ (Fig. 11d). At the simulation time of 60 years the size of the aqueous $\mathrm{CO}_{2}$ plume volume was about 5.7 times larger than that of the supercritical $\mathrm{CO}_{2}$. This is because convection increased the vertical sweep efficiency, which, in turn, increased the aqueous $\mathrm{CO}_{2}$ plume volume.

\section{CONCLUSIONS}

The mobile supercritical $\mathrm{CO}_{2}$ plume first moves upward because of its buoyancy, and then flows under the 


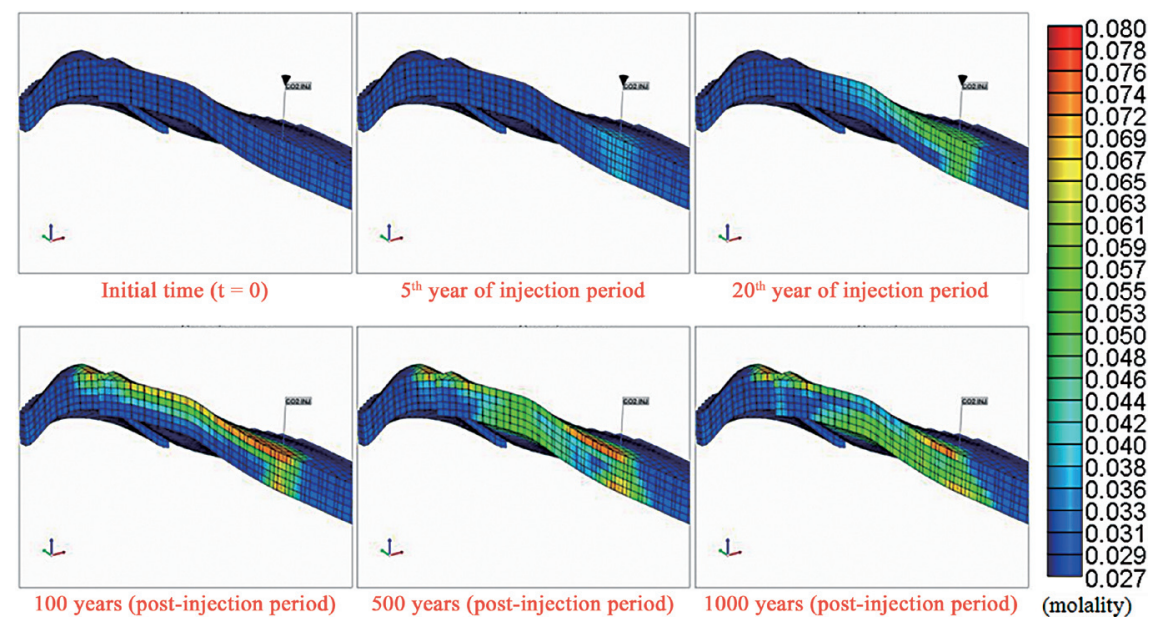

Fig. 8. Ionic phase $\mathrm{CO}_{2}\left(\mathrm{HCO}_{3}^{-}\right)$plume migration at various times: (a) initial time, (b) 5 years, (c) 20 years (or the end of the injection period), (d) 100 years, (e) 500 years, (f) 1000 years (or the end of simulation time).

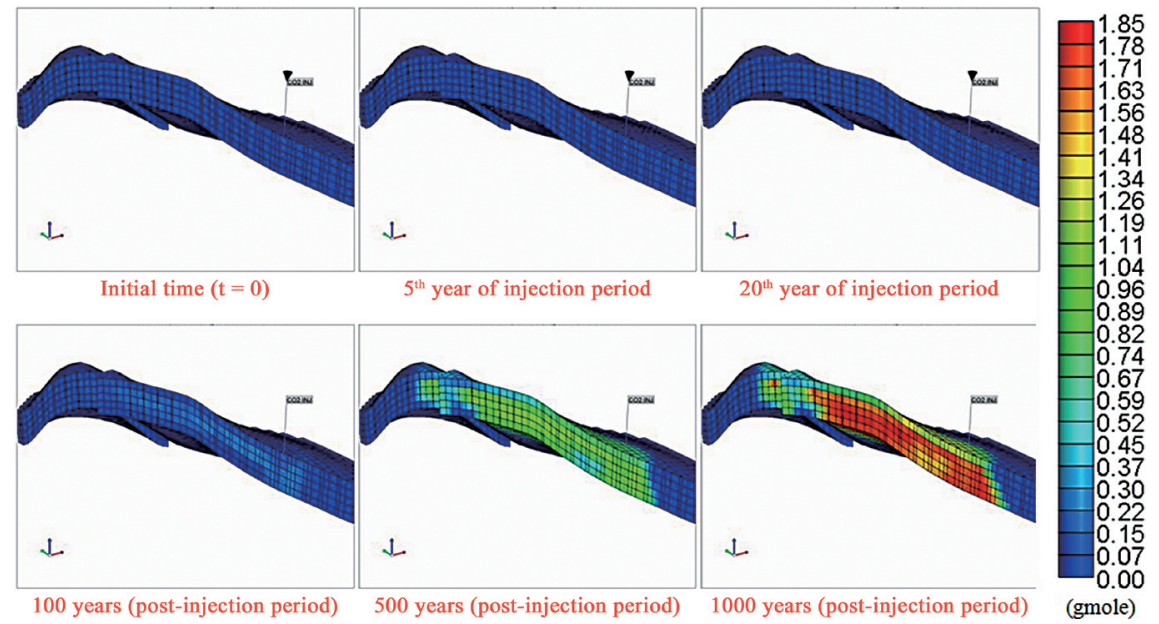

Fig. 9. Mineral (solid) phase $\mathrm{CO}_{2}\left(\mathrm{CaCO}_{3}\right)$ spatial distribution at various times: (a) initial time (the beginning of the injection period), (b) 5 years, (c) 20 years (the end of the injection period), (d) 100 years, (e) 500 years, (f) 1000 years (the end of simulation time).

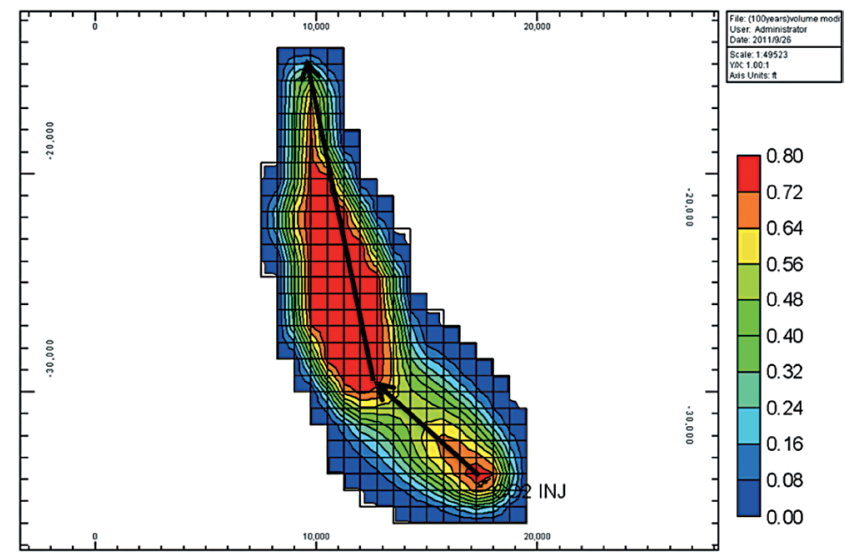

Fig. 10. Supercritical phase $\mathrm{CO}_{2}$ flow path and plume area at the end of the $\mathrm{CO}_{2}$ injection period (or the simulation time of 20 years). 
(a)

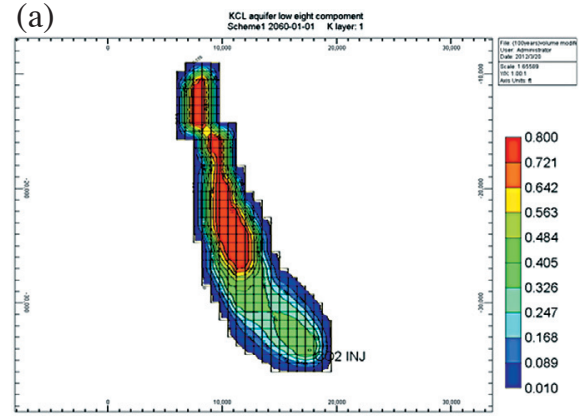

(c)

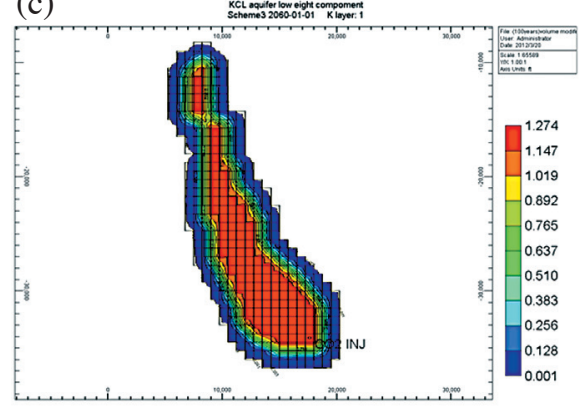

(e)

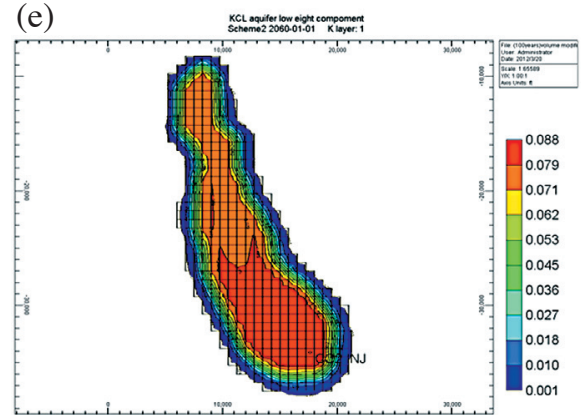

(b)
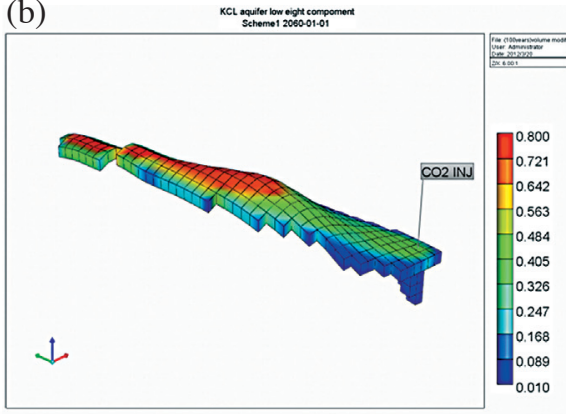

(d)
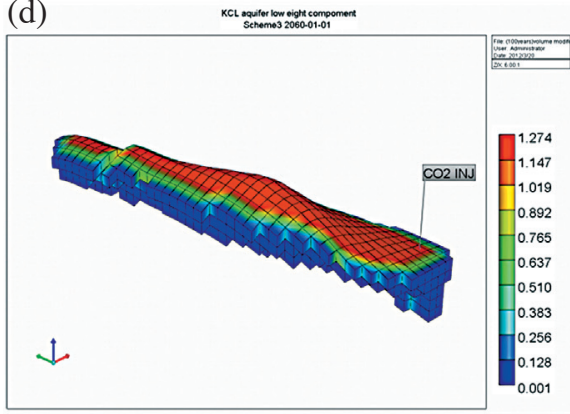

(f)

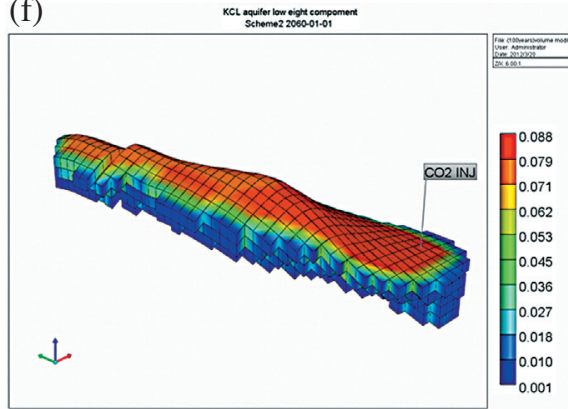

Fig. 11. Supercritical phase $\mathrm{CO}_{2}$ and aqueous phase $\mathrm{CO}_{2}$ plume area and volume at the simulation time of 60 years: (a) plume area of supercritical phase $\mathrm{CO}_{2}$, (b) plume volume of supercritical phase $\mathrm{CO}_{2}$, (c) plume area of aqueous phase $\mathrm{CO}_{2}$, (d) plume volume of aqueous phase $\mathrm{CO}_{2}$.

impermeable cap rock. In this case study, the average velocity of the supercritical $\mathrm{CO}_{2}$ plume was about $0.88 \mathrm{~m} \mathrm{day}^{-1}$ during the 20-year injection period.

Supercritical $\mathrm{CO}_{2}$ will become immobile at the rear of the moving plume due to imbibition. In the post-injection period, the quantity of the residual $\mathrm{CO}_{2}$ reached a maximum and then became smaller because of the solubility trapping mechanism. Residual gas trapping is a fast and safe mechanism for trapping injected $\mathrm{CO}_{2}$.

The plume size of aqueous $\mathrm{CO}_{2}$ is larger than that of supercritical $\mathrm{CO}_{2}$. In this study the aqueous $\mathrm{CO}_{2}$ plume volume was about 5.7 times larger than that of the supercritical $\mathrm{CO}_{2}$ at the simulation time of 60 years because convection increased the vertical sweep efficiency.

Convection causes ionic $\mathrm{CO}_{2}$ to accumulate in the down-dip of the structure and distant from the cap rock. The ionic trapping mechanism changes the $\mathrm{CO}_{2}$ into a safer ionic phase and also generates flow behavior that is low-leakagerisk and allows safe storage.
The up-dip of the structure was not the major mineralization location, because the source (bicarbonate) of the mineralization tended to sink to the down-dip of the structure.

Acknowledgements This work was supported by grant MOST 103-2221-E-006-223-MY2 from the Ministry of Science and Technology, Taiwan. The authors wish to thank CPC Corporation, Taiwan for providing the analysis data for the geological properties, reservoir properties, and rock and fluid samples.

\section{REFERENCES}

Bachu, S., 2003: Screening and ranking of sedimentary basins for sequestration of $\mathrm{CO}_{2}$ in geological media in response to climate change. Environ. Geol., 44, 277-289, doi: 10.1007/s00254-003-0762-9. [Link]

Bachu, S., 2008: $\mathrm{CO}_{2}$ storage in geological media: Role, means, status and barriers to deployment. Prog. Energ. 
Combust.,34,254-273, doi: 10.1016/j.pecs.2007.10.001. [Link]

Bachu, S., W. D. Gunter, and E. H. Perkins, 1994: Aquifer disposal of $\mathrm{CO}_{2}$ : Hydrodynamic and mineral trapping. Energ. Convers. Manage., 35, 269-279, doi: 10.1016/0196-8904(94)90060-4. [Link]

Bakker, R. J., 2003: Package FLUIDS 1. Computer programs for analysis of fluid inclusion data and for modelling bulk fluid properties. Chem. Geol., 194, 3-23, doi: 10.1016/S0009-2541(02)00268-1. [Link]

Bennion, B. and S. Bachu, 2005: Relative permeability characteristics for supercritical $\mathrm{CO}_{2}$ displacing water in a variety of potential sequestration zones. SPE Annual Technical Conference and Exhibition, Society of Petroleum Engineers, Dallas, Texas, doi: 10.2118/95547MS. [Link]

Bethke, C. M., 1996: Geochemical Reaction Modelling: Concept and Applications, Oxford University Press, New York, 416 pp.

CMG (Computer Modelling Group), 2011a: GEM Advanced Compositional and GHG Reservoir Simulator, User's Guide, Computer Modelling Group Ltd., Calgary, Alberta.

CMG (Computer Modelling Group), 2011b: WinProp Phase Property Program, User's Guide, Computer Modelling Group Ltd., Calgary, Alberta.

CPC, 2010: Simulation Study of Carbon Dioxide Geological Sequestration in Depleted Gas Reservoir, CPC Corporation, Taiwan, Cooperative Education Technical Report (Project number: FEB-9914001). (in Chinese)

Delaney, J. M. and S. R. Lundeen, 1990: The LLNL Thermochemical Database, Report UCRL-21658, Lawrence Livermore National Laboratory, Livermore, Calif.

Ennis-King, J. P. and L. Paterson, 2005: Role of convective mixing in the long-term storage of carbon dioxide in deep saline formations. Soc. Petrol. Eng. J., 10, 349356, doi: 10.2118/84344-PA. [Link]

EPA (Environmental Protection Agency), 2014: Glossary in United States Environmental Protection Agency (US EPA) website. Available at http://water.epa.gov/type/ groundwater/uic/glossary.cfm.

Flett, M., R. Gurton, and I. Taggart, 2004: The function of gas-water relative permeability hysteresis in the sequestration of carbon dioxide in saline formations. SPE Asia Pacific Oil and Gas Conference and Exhibition, Perth, Australia, doi: 10.2118/88485-MS. [Link]

GAMS (General Algebraic Modeling System), 2011a: Gamspath Geochemical Reaction Path Models, Geochemical Applications \& Modelling Software Ltd., Edmonton, Alberta.

GAMS (General Algebraic Modeling System), 2011b: Solmineq.88 Geochemical Aqueous Equilibrium Models, Geochemical Applications \& Modelling Software Ltd., Edmonton, Alberta.
Garcia, J. E., 2001: Density of Aqueous Solutions of $\mathrm{CO}_{2}$, Report LBNL-49023, Lawrence Berkeley National Laboratory.

Gaus, I., M. Azaroual, and I. Czernichowski-Lauriol, 2005: Reactive transport modelling of the impact of $\mathrm{CO}_{2}$ injection on the clayey cap rock at Sleipner (North Sea). Chem. Geol., 217, 319-337, doi: 10.1016/j.chemgeo.2004.12.016. [Link]

Gunter, W. D., B. Wiwchar, and E. H. Perkins, 1997: Aquifer disposal of $\mathrm{CO}_{2}$-rich greenhouse gases: Extension of the time scale of experiment for $\mathrm{CO}_{2}$-sequestering reactions by geochemical modelling. Miner. Petrol., 59, 121-140, doi: 10.1007/BF01163065. [Link]

Gunter, W. D., S. Bachu, and S. Benson, 2004: The role of hydrogeological and geochemical trapping in sedimentary basins for secure geological Storage of carbon dioxide. Geol. Soc. Lond. Spec. Publ., 233, 129-145, doi: 10.1144/GSL.SP.2004.233.01.09. [Link]

Gunter, W.D., S. Talman, and E. Perkins, 2008: Geosequestration geochemistry. Proceedings of 2008 Asia Pacific Coalbed Methane Symposium, 22-24 September 2008, Brisbane, Queensland.

Harvey, A. H., 1996: Semiempirical correlation for Henry's constants over large temperature ranges. AIChE J., 42, 1491-1494, doi: 10.1002/aic.690420531. [Link]

Hsieh, B. Z., L. Nghiem, C. H. Shen, and Z. S. Lin, 2013: Effects of complex sandstone-shale sequences of a storage formation on the risk of $\mathrm{CO}_{2}$ leakage: Case study from Taiwan. Int. J. Greenh. Gas Con., 17, 376387, doi: 10.1016/j.ijggc.2013.05.030. [Link]

Ide, S. T., K. Jessen, and F. M. Orr Jr., 2007: Storage of $\mathrm{CO}_{2}$ in saline aquifers: Effects of gravity, viscous, and capillary forces on amount and timing of trapping. Int. J. Greenh. Gas Con., 1, 481-491, doi: 10.1016/S17505836(07)00091-6. [Link]

IEA (International Energy Angency), 2008: $\mathrm{CO}_{2}$ Capture and Storage - A Key Carbon Abatement Option.

IPCC (Intergovernmental Panel on Climate Change), 2005: Carbon Dioxide Capture and Storage: Special Report of the Intergovernmental Panel on Climate Change, Cambridge University Press, New York, $431 \mathrm{pp}$.

Juanes, R., E. J. Spiteri, F. M. Orr Jr., and M. J. Blunt, 2006: Impact of relative permeability hysteresis on geological $\mathrm{CO}_{2}$ storage. Water Resour. Res., 42, W12418, doi: 10.1029/2005WR004806. [Link]

Kharaka, Y. K., W. D. Gunter, P. K. Aggarwal, E. H. Perkins, and J. D. Debraal, 1988: Solmineq.88: A Computer Program for Geochemical Modeling of WaterRock Interactions, Water-Resources Investigations Report 88-4227, U.S. Geological Survey, Menlo Park, California.

Kumar, A., M. H. Noh, R. C. Ozah, G. A. Pope, S. L. Bryant, K. Sepehrnoori, and L. W. Lake, 2005: Reservoir simulation of $\mathrm{CO}_{2}$ storage in aquifers. Soc. Petrol.Eng. 
J., 10, 336-348, doi: 10.2118/89343-PA. [Link]

Land, C. S., 1968: Calculation of imbibition relative permeability for two- and three-phase flow from rock properties. Soc. Petrol. Eng. J., 8, 149-156, doi: 10.2118/1942-PA. [Link]

Li, Y. K. and L. X. Nghiem, 1986: Phase equilibria of oil, gas and water/brine mixtures from a cubic equation of state and Henry's Law. Can. J. Chem. Eng., 64, 486496, doi: 10.1002/cjce.5450640319. [Link]

Lin, A. T., 2001: Cenozoic stratigraphy and tectonic development of the west Taiwan basins. Ph.D. Thesis, University of Oxford, Oxford, UK.

Lin, A. T., A. B. Watts, and S. P. Hesselbo, 2003: Cenozoic stratigraphy and subsidence history of the South China Sea margin in the Taiwan region. Basin Res., 15, 453478, doi: 10.1046/j.1365-2117.2003.00215.x. [Link]

Lin, C. K., 2007: The optimum sequestration depth for $\mathrm{CO}_{2}$ geo-sequestration. $9^{\text {th }}$ International Conference on Gas Geochemistry, Taipei.

Nghiem, L., P. Sammon, J. Grabenstetter, and H. Ohkuma, 2004: Modeling $\mathrm{CO}_{2}$ storage in aquifers with a fullycoupled geochemical EOS compositional simulator. SPE/DOE Symposium on Improved Oil Recovery, Tulsa, Oklahoma, doi: 10.2118/89474-MS. [Link]

Nghiem, L., V. Shrivastava, B. Kohse, M. Hassam, and C. Yang, 2009a: Simulation of trapping processes for $\mathrm{CO}_{2}$ storage in saline aquifers. Canadian International Petroleum Conference, Calgary, Alberta, doi: 10.2118/2009-156. [Link]

Nghiem, L., V. K. Shrivastava, D. Tran, B. F. Kohse, M. S. Hassam, and C. Yang, 2009b: Simulation of $\mathrm{CO}_{2}$ storage in saline aquifers. SPE/EAGE Reservoir Characterization and Simulation Conference, Abu Dhabi, UAE, doi: 10.2118/125848-MS. [Link]

Nghiem, L., C. Yang, V. K. Shrivastava, B. F. Kohse, M. S. Hassam, D. Chen, and C. Card, 2009c: Optimization of residual gas and solubility trapping for $\mathrm{CO}_{2}$ sequestration in saline aquifers. SPE Reservoir Simulation Symposium, Woodlands, Texas, doi: 10.2118/119080-MS. [Link]
Nicot, J. P., C. M. Oldenburg, S. L. Bryant, and S. D. Hovorka, 2008: Pressure perturbations from geologic carbon sequestration: Area-of-review boundaries and borehole leakage driving forces. GHGT9 Conference, LBNL Paper LBNL-3064E, Washington, DC.

Peng, D. Y. and D. B. Robinson, 1976: A new two-constant equation of state. Ind. Eng. Chem. Fundamen., 15, 5964, doi: 10.1021/i160057a011. [Link]

Pitzer, K. S., 1987: A thermodynamic model for aqueous solutions of liquid-like density. Rev. Mineral. Geochem., 17, 97-142.

Pruess, K., T. Xu, J. Apps, and J. Garcia, 2003: Numerical modeling of aquifer disposal of $\mathrm{CO}_{2}$. Soc. Petrol. Eng. $J ., 8,49-60$, doi: 10.2118/83695-PA. [Link]

Qi, R., T.C. LaForce, and M. J. Blunt, 2009: Design of carbon dioxide storage in aquifers. Int. J. Greenh. Gas Con., 3, 195-205, doi: 10.1016/j.jiggc.2008.08.004. [Link]

Rochelle, C. A., I. Czernichowski-Lauriol, and A. E. Milodowski, 2004: The impact of chemical reactions on $\mathrm{CO}_{2}$ storage in geological formations: A brief review. Geol. Soc. Lond. Spec. Publ., 233, 87-106, doi: 10.1144/GSL.SP.2004.233.01.07. [Link]

Shaw, C. L., 1996: Stratigraphic correlation and isopach maps of the western Taiwan basin. Terr. Atmos. Ocean. Sci., 7, 333-360.

Thibeau, S., L. X. Nghiem, and H. Ohkuma, 2007: A modelling study of the role of selected minerals in enhancing $\mathrm{CO}_{2}$ mineralization during $\mathrm{CO}_{2}$ aquifer storage. SPE Annual Technical Conference and Exhibition, Anaheim, California, U.S.A., doi: 10.2118/109739MS. [Link]

Wu, J. C., W. R. Chi, M. H. Wang, C. C. Tsia, Y. Y. Lee, and C. C. Chang, 2005: The study of nannoplankton biostratigraphy and paleoenvironments in Peikang area southwestern Taiwan, Annual Meeting of Geological Society, Taipei. (in Chinese)

Xu, T., J. A. Apps, and K. Pruess, 2004: Numerical simulation of $\mathrm{CO}_{2}$ disposal by mineral trapping in deep aquifers. Appl. Geochem., 19, 917-936, doi: 10.1016/j.apgeochem.2003.11.003. [Link] 